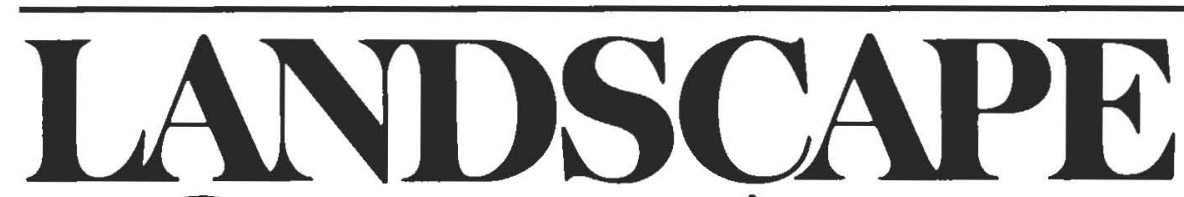

Design, planning and management of the land 


\section{Residential Subdivision Identity in Metropolitan Phoenix}

\section{Kevin S. Blake and Daniel D. Arreola}

Kevin S. Blake is a Ph.D. candidate in geography at Arizona State University. He has a B.S. in business administration and an M.A. in geography from the University of Kansas. His research interests include mountain symbolism, place imagery, and landscape identity.

Daniel D. Arreola is professor of geography at Arizona State University. He holds a B.A. from UCLA, an M.A. from California State University, Hayward, and a Ph.D. from UCLA, all in geography. His research interests include urban landscapes and place identity. He is co-author of The Mexican Border Cities: Landscape Anatomy and Place Personality.

\begin{abstract}
Residential subdivisions are often criticized for a lack of identity, yet this systematic analysis of subdivision names and landscape traits finds that identity actually flourishes in metropolitan Phoenix subdivisions. Identity varies according to the location and age of developments, as well as the residents' income level, race, and ethnicity. Subdivision names with environmental themes, especially height, have increased in frequency since 1973. Higherpriced areas set the standard for name themes that are then borrowed by middle-income neighborhoods. Field observations in twelve subdivisions reveal that personal landscape signatures, common in all developments, are more important for the projection of identity in lower-priced areas, whereas institutional signatures are more often the distinguishing characteristic of higher-priced subdivisions.
\end{abstract}

$\mathrm{R}$ esidential subdivisions in metropolitan Phoenix supposedly have an identity crisis. Homogenous developments of sprayon stucco houses that result in a sterilized version of the desert ecosystem are portrayed as a villainous trend that is wiping out landscape character (Hemphill and Murphy 1994). The tirade against the ubiquitous Neo-Mediterranean-style architecture, red tile roofs, and beige house colors of newer subdivisions reached a fevered pitch in a newspaper article titled "Valley of the Tiles Drowning in Fake-Mexican Houses" (Kroloff 1993) (Figure 1). Phoenix has been said to lack neighborhood identity, and one authority asserted that newer cities like Phoenix have less identity than older ones like Tucson (Sargent 1988; Hough 1990). Each of these comments is tenable, however, only as a generalization, because the conclusion may be far different after a systematic analysis of individual subdivisions.

The concern over the loss of identity in cities and residential areas is not new, nor is it unique to Phoenix (Jackson 1994). The first section of the Urban Land Institute's residen- tial planning handbook encourages builders to not use the "cookie-cutter" approach, applying old products on new locations (Bookout et al. 1990).

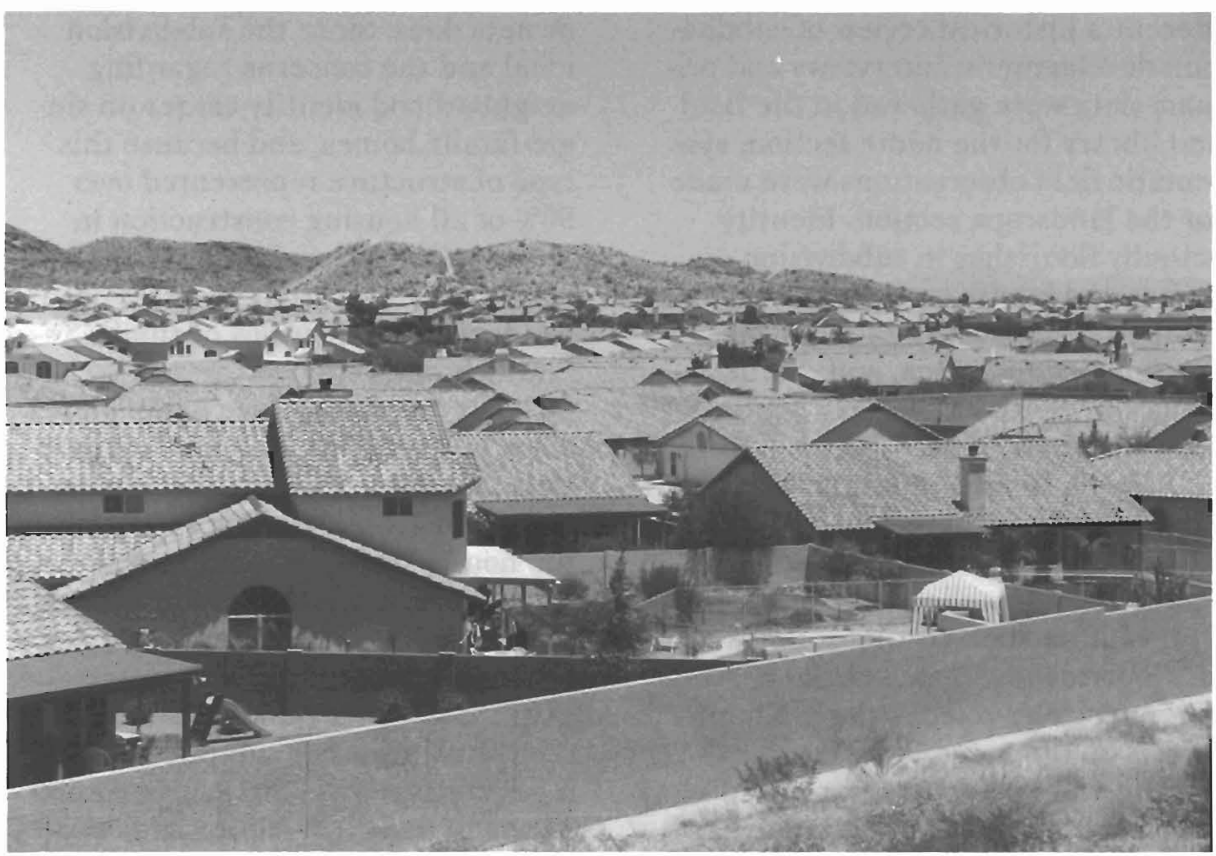

Figure 1. Red and pink concrete tile roofs dominate this subdivision landscape near South Mountain in southeastern Phoenix.
This same planning document is criticized, however, for having "constrained possibilities and reduced the likelihood of idiosyncratic developments 
and the happy accidents of juxtaposition" (Relph 1987, p. 143). The issue of neighborhood identity attracts much attention because standardized automobile subdivisions that are typical of suburbia are one of the "model landscapes of American community" (Meinig 1979, p.167). Yet, herein lies a paradox: the criticism of subdivisions for having a lack of identity and the idealization of suburban subdivisions as representative of an American arcadia. Metropolitan Phoenix is fcrtile ground to explore this issue of subdivision identity, and not only because tract housing seems to sprawl across every view. Phoenix is touted in two recent publications, Edge City and Magic Lands (Garrcau 1991; Findlay 1992), as the essence of a master planned subdivision landscape.

The widespread dissatisfaction with neighborhood quality that is claimed by some authors mandates a better understanding of what identity residential areas have and how they acquire it (Lansing and Marans 1969). This paper explores the identity projected by subdivisions in Phoenix through a comparative analysis of subdivision names from two time periods and detailed field observations made of landscape characteristics in twelve residential areas. We first define the scope of the terms "subdivision" and "identity," and then present a historical review of subdivision development. Interviews and primary data were gathered in the field and library for the name section; systematic field observations were made for the landscape section. Identity actually flourishes in subdivision names and landscapes, and it will be compared across variables of time, location, income, race, and ethnicity.

\section{The Subdivision Image}

In its simplest form, a "subdivision" is a place where developers have platted large parcels of land into smaller lots, installed the utility and street infrastructure, and sold the lots individually. A residential subdivision typically refers to single-family houses on improved lots. "Custom" homes, designed to fit the needs of each buyer, were at one time the norm in residential subdivisions. Over the last fifty years, a subdivision has become practically synonymous with privately-developed "tract" housing, in which often only one builder sells as a package a completed house on a lot. In a tract development, the buyer chooses from models that are of similar appearance with a few basic variations. Although residential areas are built in a varicty of terrains, geographer Donald Meinig (1979, p.169) expressed a popular suburban subdivision image with these words: "low, wide-spreading, single-story houses standing on broad lots fronted by open, perfect green lawns; the most prominent feature of the house is the two-car garage opening onto a broad driveway, connecting to the broad curving street ..." Architect Robert Stern (1986) relates a similar vision of the American suburban scene.

A neighborhood or residential area is a geographically elastic concept that could be perceived as either a larger entity than the individual subdivisions that constitute it or as a small section of a subdivision. A "master planned community" is a large-scale development under one subdivider that may involve multiple builders. Master planned communities have covenants, conditions, and restrictions attached to each lot, and they usually have common areas that are maintained with assessed homeowners dues. Since the subdivision ideal and the concerns regarding neighborhood identity center on single-family homes, and because this type of structure represented over $90 \%$ of all housing construction in metropolitan Phoenix during the early 1990 s, this study focusses on residential subdivisions of singlefamily homes.

By "landscape" we mean all features of the residential development that are visible from its automobile and foot paths, including attributes of the houses, yards, streets, and alleys. Thus, a residential landscape includes such traits as its architectural styles, ornamental plantings, and street plan. As we use it, "identity" refers to the connotations or subjective meanings projected by a distinctive combination of name themes or landscape characteristics. Often thought to imply a sense of belonging to a particular group, identity also encompasses the character or unique qualities of a place that enhance the feclings of attachment. Identity is a key component of what makes up the popular perception of a place and gives it what Lynch (1960) called "imageability," a high probability of evoking a strong image. The identity of residential areas is a strong influence on the search for new housing, yet most studies have not dealt adequately with the implications of neighborhood name, characteristics, and reputation (Palm 1982; Godfrey 1988).

Subdivision Growth and Popularity. Well-known pre-automobile efforts to create planned residential arcas with secluded, affluent identities designed for upper-middle-income families include Riverside, Illinois, in 1869 and Roland Park, Maryland, in 1891 (Jackson 1985; Stilgoe 1988). Subdivisions such as these were not the norm in that era, but they were the precursors of the planned subdivisions that are today ubiquitous, except that their compact layout was unsuited to the automobile. Two important preWorld War II subdivisions were Kansas City's Country Club District, started in 1922, and Radburn, New Jersey, designed in 1928 by Clarence Stein and Henry Wright. The developer of the still-popular Country Club District, J. C. Nichols, tried to heighten community identity through the development of country clubs, the subsidizing of churches and schools, and the creation of neighborhood contests and social gatherings (Worley 1990). Nichols correctly surmised that a well-defined identity would be a powerful marketing tool. The residential sections of his development featured winding streets, low house densities on treed lots, deed restrictions, and homeowners associations. Radburn also influenced the subdivision ideal through its creation of neighborhoods focussed upon themselves, with an attractive design of homes clustered around open spaces and separate routes for pedestrians and cars (Relph 1987).

In the last half of this century, the vertical economic integration of subdivision development has become common, with the same company 
subdividing land, improving the site for residences, and erecting the houses. The most famous example of one of the first large-scale, mass-produced tract housing developments is Levittown, New York, started in 1947. It enhanced community identity through the use of curvilinear streets, neighborhood parks, and some facade variations to provide house individuality (Gans 1967).

As in other cities during the late 1800 s, subdivision locations in Phoenix were strongly influenced by street railway development (Luckingham 1989). Additions occurred west and east of the original business district, but by the 1920s, the trend was firmly established for the most elegant of these, including carly automobile suburbs, to be located north of downtown on higher ground and distant from the commcrcial core (Sargent 1988). Residential dispersion away from strcetcar lines started shortly after 1900 , and streetcars stopped operating in 1948. Typical of this era was the purchase of a lot, followed by the custom construction of a house; tract housing did not become common until after World War II.

Phoenix expericnced explosive automobile suburb growth in the postwar years. Sun City opened in 1960 and soon had an identity as the model of a well-planned retircment landscape, a cultural accomplishment for the urban West (Findlay 1992). In the early 1970s, planned communities and retirement centers sprouted throughout the metropolitan area, a trend that continues unabated. Currently, subdivisions are pushed farther out to large tracts on the periphery of the city because builders seek cheaper land and cconomies of scale, and some municipalities are reluctant to zone for single family houses that generate less property tax revenue than other uses. In recent years subdivision "campout" openings, those at which prospective home buyers and real estate agents wait in line for several days in advance of the commencement of lot sales, have been spurred by well-funded marketing efforts centered around a distinctive environmental identity like mountain foothills.

\section{Identity in Subdivision Names}

Subdivision names have been cffcetively used throughout the country to enhance the image of a community and project a prestigious identity (Schwartz 1980; Weightman 1981). Housing development names are psychologically potent in their ability to conjure widely differing images (Banerjee and Baer 1984), and they are typically required on subdivision plat maps. As symbolic devices that enhance the identity of subdivisions, names also reflect place personality (Peterson and Saarincn 1986).

Although the name for a residential area is a leading source of identity for all income groups, little is known about what identities are communicated through names and how these vary by house value, time, and area.

Names are institutional creations, originating with a developer and chosen with marketing forcmost in mind. The contrasting identity projected by subdivisions named "Northtown" versus "West Shore at Desert Harbor" causes builders to be advised by the Urban Land Institute to pay close attention to the choice of a subdivision name (Bookout et al. 1990). Interviews with two people who have participated in the naming of subdivisions revealed that, contrary to this advice, many names in Phoenix are chosen without much thought (Martin 1994; Shattuck 1994). Borrowing names from other housing markets is common, especially those in Southern Cialifornia, Colorado, and Texas. Only developments with either a distinctive setting or architecture cause builders to carefully select a name.

Once a name is established, its identity is projected via several social networks as well as through landscape features. Subdivision names are a standard data item in the real estate multiple listing service, so realtors and prospective buyers constantly evaluate a subdivision, in part, on its name. Even if the subdivision name no longer appears in the landscape, vernacular usage by long-term residents serves to continue the projection of the name identity. Homeowners associations and their newsletters also can project subdivision name identity to residents, city officials, and vendors of services to the association.

Using dat a compiled by Landiscor Aerial Photo, we classified new subdivision marketing names into themcs for 1993 and 1973, the most recent and earliest complete years of data available (Greater Phoenix Housing Study). Names were evaluated for any subdivision active in 1993 that had a cumulative total of at least 100 housing starts; thus, the names with the broadest exposure are represented in this study. Cumulative housing start data were not available for 1973, so all subdivision names were tallied. This method resulted in the analysis of 221 names for 1993 and 134 for 1973. Tuan (1974) suggested that the most popular subdivision name themes are nostalgic ones that evoke a rural idea, something bucolic or romantic. Almost any name can be perceived as exemplary of these types, so for this study more specific thematic name categories were determined by a sampling of names from both ycars. Table 1 presents the results from each year. Namcs with more than one theme, such as Sun Lakes, were tallied twice, once each for the themes of sun and water. Any Spanish word in a name, such as "vista," resulted in a tally for the Spanish theme.

Overall, names projecting an environmental identity have increased in popularity since 1973. Names with more than one theme are also more common in 1993, perhaps reflecting a desire of builders to achieve a better imageability with a name. Natural features that are threatened by development or that are seen as distinctive selling features, such as water, deserts, and particularly mountains, are increasingly symbolized in subdivision names. Environmental names reflect a trend by builders to respond to preservationist concerns by at least giving the impression that developments are planned in harmony with nature. Prestige is a rather nebulous category, primarily containing names with seclusion, elitist, or English connotations. Prestige names also have become more common since 1973, perhaps reflecting the continued broad acceptance of English landscape tastes (Hugill 1986). 
TABLE 1.

Percentage of Subdivision Names Containing Selected Themes, 1973 and 1993.

\begin{tabular}{llrlr}
\hline & & & \multicolumn{1}{c}{1993} & \\
Theme & Example & Total & Example & Total \\
\hline $\begin{array}{l}\text { Environmental } \\
\text { Height }\end{array}$ & Hillcrest East & 7 & Crystal Ridge & 26 \\
Lush foliage & Olive West & 28 & Orchid Point & 16 \\
Water & Canyon Creek & 2 & Westbrook Village & 14 \\
Desert & Sands Oasis & 5 & West Shore at Desert & \\
& & & Harbor & 8 \\
Sun & Suntown & 5 & Sun Lakes & 4 \\
Other & Skyview West & 7 & Summer Breeze & 4 \\
Subtotal & & 54 & & 72 \\
Spanish & Rancho Saguaro & 27 & Vista de Oeste & 18 \\
Prestige & Newcastle Estates & 11 & Warner Ranch Enclave & 18 \\
Indian & Thunderbird Village & 2 & Arrowhead at the Shores & 5 \\
Other & Northtown & 13 & Festival & 7 \\
\hline
\end{tabular}

Source: Compiled from Landiscor's 1973 and 1993 Greater Phoenix Housing Studies. Percentages do not add to 100 because some names contain more than one theme. 134 and 221 names were categorized for 1973 and 1993, respectively.

The drop in the frequency of lush foliage and Spanish names since 1973 can be partially explained by the declining popularity of "glen" and "villa" as subdivision monikers. Furthermore, ornamental planting tastes in Phoenix have evolved since the 1970s to a much higher acceptance of xeriscaping and low-water use exotic and native vegetation. The rise in the popularity of desert plantings is reflected in both the higher percentage of desert names and in the lower percentage of lush foliage names in 1993 compared to 1973. The Sonoran Desert, especially the upland palo verdesaguaro association, has achieved the status of a conventional symbol for Arizona front yards (Hecht 1975).

Landiscor's housing data are compiled by area and contain housing values, so we compared name themes by areas and house prices within metropolitan Phoenix. Although the relationship between residential area names and the actual landscape may be quite arbitrary, we found this to not always be the case (Relph 1987). Height and desert names have been most common in the Northeast Valley, where subdivisions are in the closest proximity to existing and proposed mountain preserves. Water names are significantly more common in the West Valley and Southeast Valley, where huge tracts of flat land have permitted lake developments. Indian names are by far most frequent in the West Valley, a legacy of the success of the Arrowhead Ranch master planned community in Glendale.

An earlier study of name type variance by class in Mexico found elite subdivisions having the more exotic names, but the middle-class names were converging with those of the elite class (Arreola and Curtis 1993). The same convergence process has been underway in Phoenix since 1973 with regard to height, water, desert, and lush foliage names. A divergence has occurred, however, between the middle- and upperincome area names with prestige or Indian themes. There were virtually equal rates of these themes in 1973, but in 1993 the higher-priced subdivisions feature these names far more frequently. Apparently, builders of clite homes seek to differentiate their products from those for the middleincome groups by emphasizing new themes, and then middle subdivisions borrow name themes from upper developments.

Subdivision names can be long lived, especially in the names of local businesses or churches. Arcadia, plat- ted in 1919 between the Arizona Canal and Camelback Mountain, survives in name among some one dozen commercial locations outside the original subdivision boundaries. The name persists in spite of the re-platting of the subdivision in 1929 and the development of the area under several different names. A similar attachment of subdivision name to surrounding establishments is found for Encanto, an early auto suburb near downtown, suggesting that names may be more resilient in higher-income districts.

\section{Identity in Subdivision Landscapes}

Landscape objects have different symbolic meanings to different groups and are crucial markers of group identity (Duncan 1973; Winters 1989). This study identifies those traits through a detailed landscape analysis. It is hypothesized that subdivisions have clear identities characterized by a few salient at tributes. Our familiarity with residential areas in Phoenix played a role in selecting subdivisions, in that four of the developments chosen represent those that we either live in or had visited prior to this study, Other subdivisions were selected after field reconnaissance and interviews with real estate professionals (Martin 1994; Richter 1994) and planners (Brennan 1994; Pascoe 1995).

Our goal was to choose subdivisions representative of metropolitan Phoenix, considering several variables: location, age of area, race and cthnicity of residents, house value, and type of development (master planned, tract, or custom). These characteristics were chosen because they have been linked to the identity of residential areas in other studies (Rowe 1991; Girling and Helphand 1994). Our method involved comparing subdivision identity between and within variables. A random sclection of subdivisions would not have guaranteed that comparisons could be made among all of these conditions. Average house value estimates are used to define income level divisions in this study. The locations of the twelve subdivisions that were selected 
for in-depth landscape reading are shown on Figure 2, and selected data for each are listed on Table 2. Arcadia Village in Chandler is a completely separate entity from the Arcadia district in Phoenix. The "identity tag" column contains nicknames we created for each subdivision that capture a main aspect of its identity in a few words.

Subdivisions with higher percentages of Hispanics and Blacks than the county average were identified through field observations and census data (U.S. Bureau 1993) to represent the two largest minorities in metropolitan Phoenix. ${ }^{2}$ Holmes Addition, near the Mormon temple and a ward chapel in Mesa, was selected to possibly represent a higher than average percentage of Mormons, another large subgroup. Sunland Village, a master planned retirement subdivision, was chosen because retiree areas are central to the image of Phoenix. More than one subdivision was examined in the Encanto and Sun Valley Estates areas because boundaries between subdivisions in these areas are nebulous, and these districts have an identity that emanates from and yet transcends residential areas. Subdivisions of various ages were chosen for an evaluation of how identity is dependent upon the age of a development. More subdivisions in the mid-range of house values were chosen than other levels because a majority of Americans define themselves as "middle class" (Leroux 1993), and most new subdivision housing is marketed to this group.

Reading the Subdivision Landscape.

An alternative to understanding group identity through perception surveys of people is a method called "reading the landscape" (Lewis 1979). Scholars have effectively read

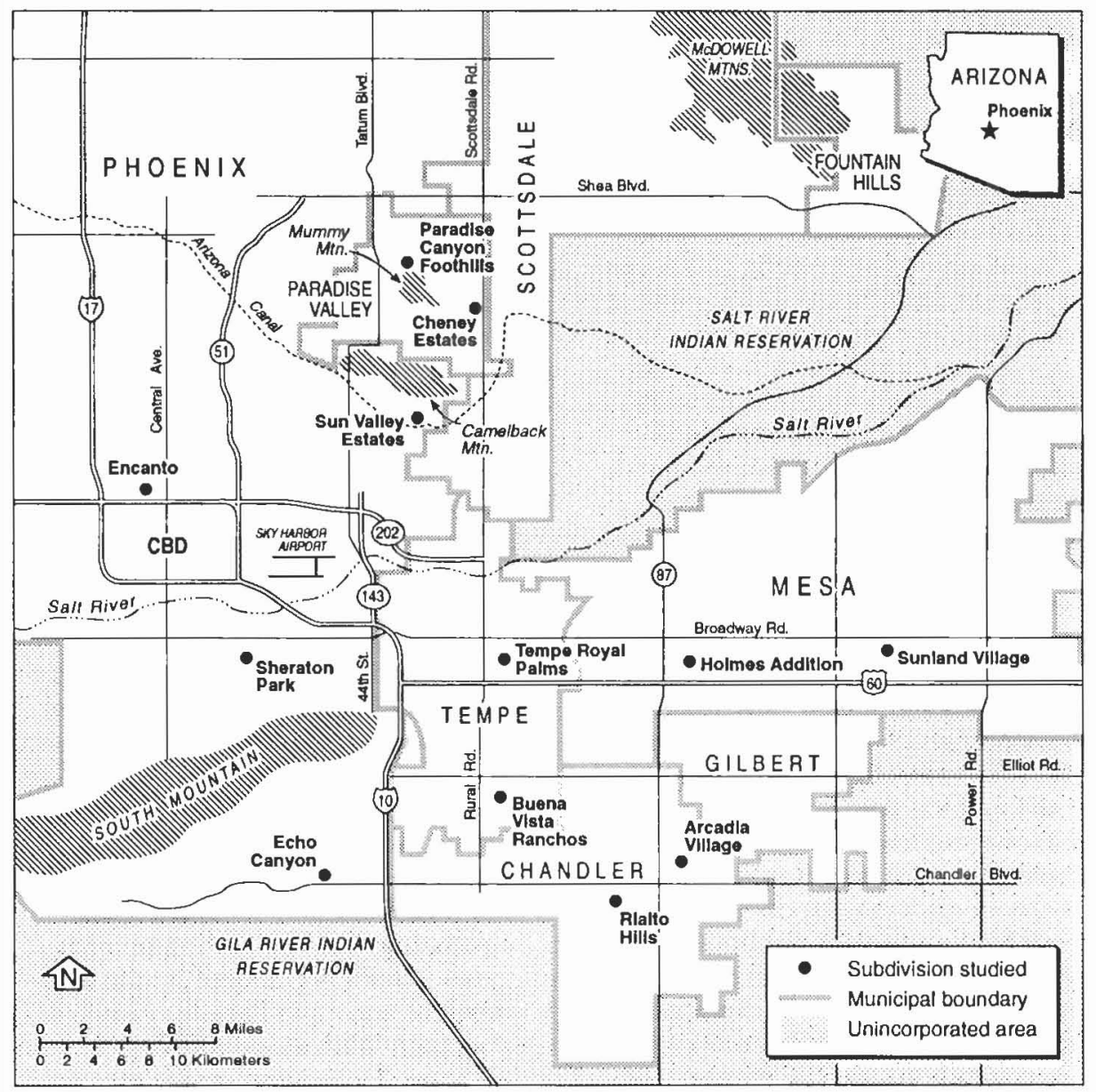

Figure 2. Locations of the twelve metropolitan Phoenix subdivisions examined.

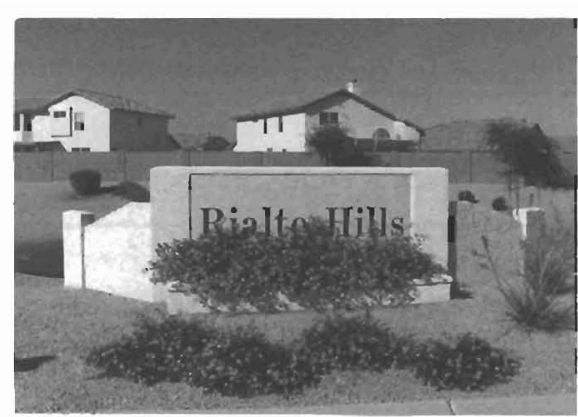

Figure 3. Rialto Hills entryway monument, an institutional signature that produces character for the community and helps to set it apart from all others.

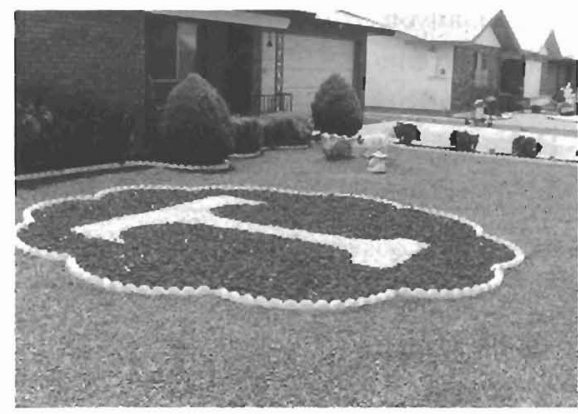

Figure 4. This rock design forming a " $\mathrm{T}$ " is a personal signature in Sunland Village. Other yard art examples are scattered about in the green-painted gravel.

the landscape to determine the various subjective meanings of a place, such as its symbolism or identity, that could be difficult for people to articulate in an interview (Meinig 1979; Zelinsky 1988). Place personality and identity are manifest in characteristics of the built environment that have becn labeled "landscape signatures" (Salter 1978). These signatures can be divided into "institutional" and "personal" elements. Figure 3 shows an example of an institutional signature, an entry sign placed by the collective action of a group or corporation, such as a homeowners association or developer. The freedom of expression allowed in this signature may be limited, however, by local ordinances restricting the sign's appearance. Ornamentation placed in a yard is an example of a personal signature, and its regulation is primarily dependent upon the restrictive mentality of a homeowners association or 
TABLE 2.

Selected Data for Subdivisions Examined.'

\begin{tabular}{|c|c|c|c|c|c|c|}
\hline Name & $\begin{array}{l}\text { Years } \\
\text { Built }\end{array}$ & $\begin{array}{c}\text { Development } \\
\text { Type }\end{array}$ & $\begin{array}{l}\text { Mean } \\
\text { House } \\
\text { Valuc }\end{array}$ & $\begin{array}{c}\text { Ethnicity } \\
\text { \& Race } \\
(\mathrm{A}-\mathrm{H}-\mathrm{B} \%)\end{array}$ & $\begin{array}{l}\text { No. of } \\
\text { Houses }\end{array}$ & Identity Tag \\
\hline \multicolumn{7}{|l|}{ Upper-Income } \\
\hline Paradise Canyon Foothills & $1974-1986$ & C & $\$ 676,000$ & $100-0-0$ & 32 & Sky Drives \\
\hline Cheney Estates & 1994-present & MPG-C & $\$ 691,000$ & N/A & 80 & Elevated Entries \\
\hline \multicolumn{7}{|l|}{ Middle-Income } \\
\hline Encanto & $1929-1941$ & $\mathrm{C}$ & $\$ 230,000$ & $84-12-2$ & 233 & Valley of the Palms \\
\hline Sun Valley Estates & $1957-1962$ & $\mathrm{~T}$ & $\$ 218,000$ & $98-1-1$ & 181 & Sunken Citrus \\
\hline Buena Vista Ranchos & 1973-1994 & MPC-C & $\$ 230,000$ & $92-5-1$ & 156 & Horse Heaven \\
\hline Tempe Royal Palms & 1966 & $\mathrm{~T}$ & $\$ 94,000$ & $88-7-2$ & 297 & Boats and Basketball \\
\hline Sunland Village & 1982 & MPC-T & $\$ 96,000$ & $99-1-0$ & 205 & Name Plates and Home States \\
\hline Rialto Hills & I991-1993 & MPC-T & $\$ 100,000$ & $80-15-1$ & 193 & Spray-on Spanish \\
\hline Echo Canyon & 1992 & MPC-T & $\$ 127,000$ & $90-5-0$ & 98 & Packaged Ponds and Lawns \\
\hline \multicolumn{7}{|l|}{ Lower-Income } \\
\hline Sheraton Park & 1963 & $\mathrm{~T}$ & $\$ 50,000$ & $0-7-90$ & 162 & Barred Panes and Bright Paint \\
\hline Holmes Addition & 1971 & $\mathrm{~T}$ & $\$ 66,000$ & $74-20-3$ & 104 & Patchwork Quilt \\
\hline Arcadia Village & $1973-1974$ & $\mathrm{~T}$ & $\$ 65,000$ & $69-26-2$ & 141 & Mulberry Lane \\
\hline
\end{tabular}

Source: Field observations, 1994 Maricopa County plat maps and tax records, and U.S. Bureau of the Census (1992). The "Development Type" column indicates: C (custom houses), T (tract houses), MPC-C (master planned community with custom houses), MPC-T (master planned community with tract houses). The percentages in the "Ethnicity \& Race" column correspond to: A (Anglo), H (Hispanic), B (Black). Other groups account for less than five percent in all subdivisions. Resident data for the incomplete development of Cheney Estates were not available.

the covenants, conditions, and restrictions attached to the deed (Figure 4). A landscape study can reveal how identity is projected, who controls the projected identity, and who receives the message. Patterns of similarities and differences across variables of social group, time, and space may also be gleaned from the landscapc. We studied the "housescapes" (Arreola 1988) and streetscapes of each subdivision and designated observed characteristics as common, occasional, or rare. Through field reconnaissance and a review of other urban landscape studies, we developed a two-page tally sheet of subdivision traits to use while making field observations. Our ficld methods involved driving the perimeters of each subdivision to get a sense of the place and to look for "turf markers," enclosures or signs that define territory (Clay 1973). Then each street in the subdivision was walked, of ten twice, while taking notes and photographs for later review. We recorded the frequency of characteristics and examples of distinctive elements.
After the pedestrian survey was finished, we again drove through the subdivision, crosschecking certain features. We determined the boundaries of subdivisions using plat maps as well as landscape features, such as walls and signage.

Upper-Income Subdivisions. Paradisc Canyon Foothills, as its name suggests, both ascends along and affords hillside vicws from the northwest face of Mummy Mountain, a defining landform of Paradise Valley. Custom ranch houses on acre lots, some carved out of rock slopes, feature ornamental plantings, either a managed desert look of carefully placed cacti, or a lush style with sweeping green lawns and leafy olive trees. While the occasional tennis court and flagpole testify to exclusive personal recreation and patriotic spirit, the most common signatures of the subdivision are circular driveways leading to a formal house cntryway and to garages accommodating up to six cars (Figure 5). Because street lights do not exist, driveways are typically framed by illuminated four-foot-tall masonry posts, and other custom designed outdoor light- ing is common. Several homes included security gates at the driveway entrance and, as expected, private security signs are abundant. The airy view lots, sloping circular driveways, and steep streets climbing the mountain project a "Sky Drives" identity for this elite subdivision.

Cheney Estates is a securityguarded, gated, and walled subdivision on the east boundary of the Town of Paradise Valley where it abuts Scottsdale along the Indian Bend Wash. It was the only subdivision studied that is under construction, although some dozen homes are completed and a f cw are occupied. Large homes $(4,000-5,000$ square feet) on mostly one-half to three-quarter-acre flat lots create an unusually high density for an upper-income subdivision. While many homes include small pools, and a few occupy larger cul-desac lots, front and backyard space consisting of mixed xeriscape with grass islands is cramped by the standards of homes in Paradise Cianyon Foothills. With space wanting, it is no surprise that several tennis courts on 
the edge of the development serve as a potential gathering node for residents. A single builder whose trademark Neo-Mediterranean houses feature grand porticoes focussed on tall decorative doors stamp this subdivision as "Elevated Entries." Uniformity that results from this type of institutional landscape control may explain why personalized yard ornaments, a fountain and a large sculpture, already decorate the front lawns of two finished homes in this still accreting subdivision.

Middle-Income Subdivisions. ${ }^{3}$ The Encanto-Palmcroft neighborhood north of downtown Phoenix contains more institutional signatures than most subdivisions, with its decorative lamp posts and turf-marking "historic district" and "no thru traffic" signs. Massive palms planted at the street edge create a "Valley of the Palms" identity (Figure 6). Alarm system signs, broad expanses of grass and lush ornamental plantings, front property line hedges, and tile address numbers are frequent personal signatures that, in combination with the streetscape features, reflect a neighborhood identity concerned both with ornamentation and defense of its turf. This is the most architecturally diverse subdivision that was observed, with several homes on the National Register of Historic Places. The identity of Encanto (Spanish for "enchantment") is projected via its designation by the city as a historic district and as the namesake for a park, local businesses, and churches, as well as a Phoenix urban village.

Nestled south of the shapely mass of Camelback Mountain in Phoenix, Sun Valley Estates and the other subdivisions surveyed in the Arcadia district have citrus tree-filled lawns with edge berms to accommodate flood irrigation, giving the appearance of "Sunken Citrus" (Figure 7). Irrigation pipes and valves are common landscape features, but their size and frequency is rivaled by massive, masonry mailboxes. Arcadia's landscape fits its name: profuse green foliage drapes the expansive, ranchstyle homes set on large lots. There is little deviation in the basic style of the homes, but variety exists in facade materials. Individuality in the subdivision is expressed in the com-

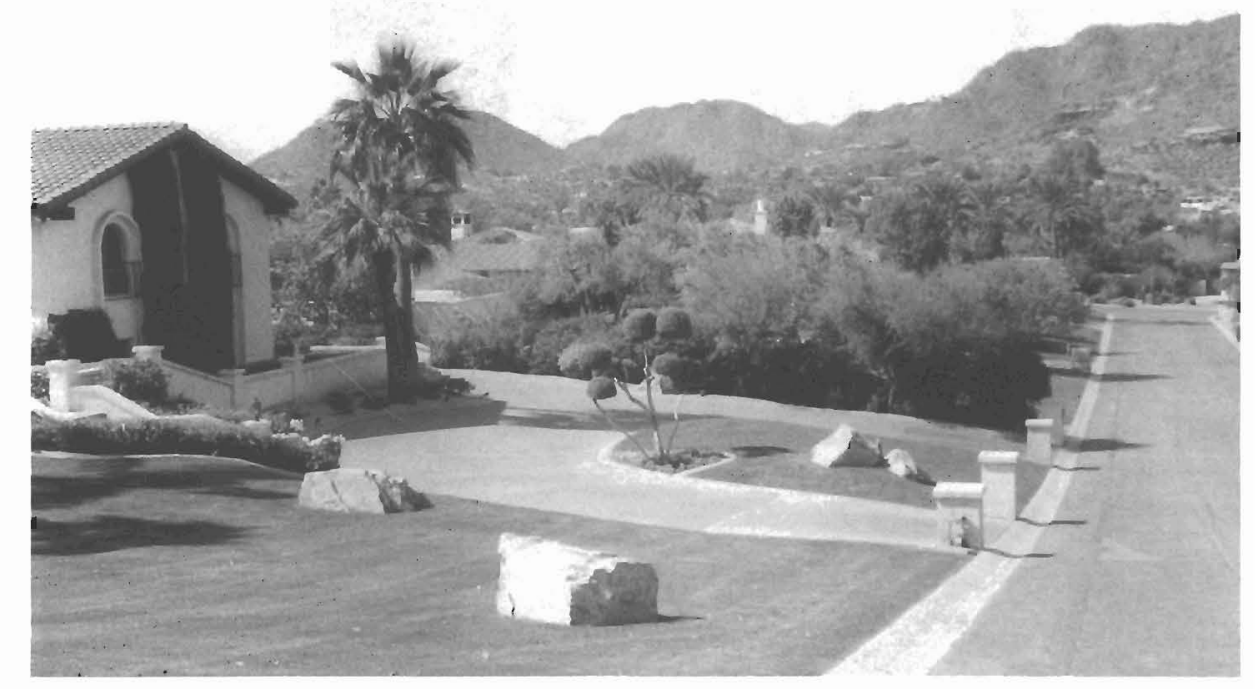

Figure 5. On a shoulder of Mummy Mountain, Paradise Canyon Foothills features circular "Sky Drives" leading to formal entryways and multi-car garages.

mon yet diverse collection of yard art (ornamentation), ranging from an Indian statue to ornate driveway corner posts. The neighborhood's character, exemplified by such features as house style, yard art, or its dominantly non-Hispanic white population, does not match its abundant Spanish street names; only the lawn maintenance crews are Hispanic.

The essence of identity in Buena Vista Ranchos is communicated by the small signs that say "horse path only" resting next to the elaborate entryway monuments and double exterior walls of this subdivision in south Tempe. At the center of the development is a huge grassy area of community facilities including tennis courts, pool, playground, picnic ramada, and ball field, but the largest are the horse paddock and exercise area (Figure 8). We label the horse facilities area an "epitome space" because it captures the essence of the community identity and is a place for residents to gather (Clay 1973). Many Buena Vista Ranchos back yards are enclosed with horse fencing, and some have their own stables. Horse paths run among the houses and around the periphery, making this a veritable "Horse Heaven." As in Encanto, identity is expressed more through distinctive custom house styles than through yard art. More than any other feature, however, identity is expressed here in how horses are accommodated, as attested by the for sale sign that advertises "horse set-up."

As the average house value declines in the group of middle subdivisions, custom homes on large lots give way to tract housing on smaller lots. Ranch-style homes painted with a wide variety of muted colors and topped by gray or brown roofs characterize Tempe Royal Palms. More variable than the house style are the ornamental planting designs and mailbox placement. Some properties have mailboxes on the house, but a large number instead have one at the street. About one-half of the front yards are devoted to xeriscaping, with the other half in grass; curiously, royal palms are not abundant. Lawns rarely have front property line dividers unless they abut a rock yard, in which case a substantial barrier may exist. The most revealing landscape signatures of this subdivision's projected identity as a place of middleincome families and recreation tastes can be summed up with "Boats and 


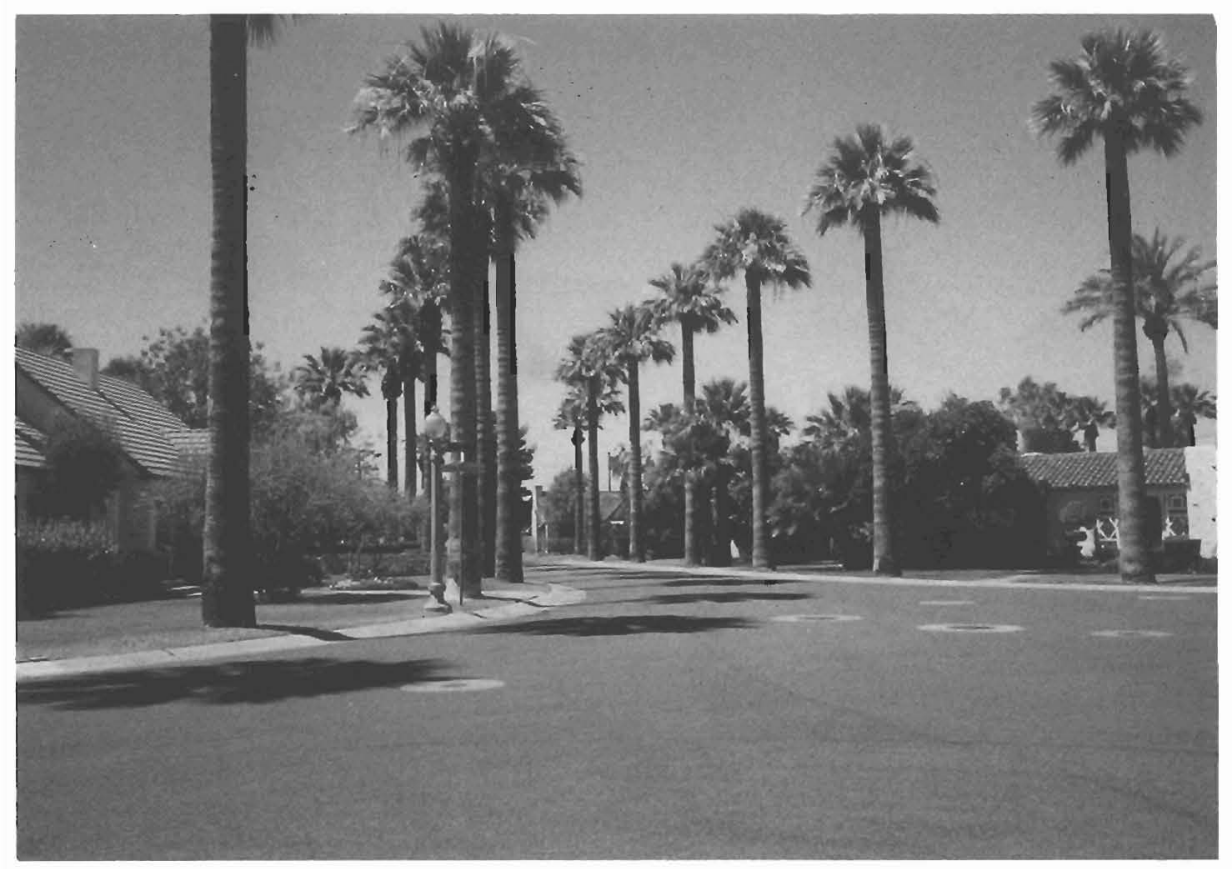

Figure 6. The institutional signatures of the Encanto-Palmcroft "Valley of the Palms" streetscape include massive palms and historic district signs mounted on decorative lamp posts.

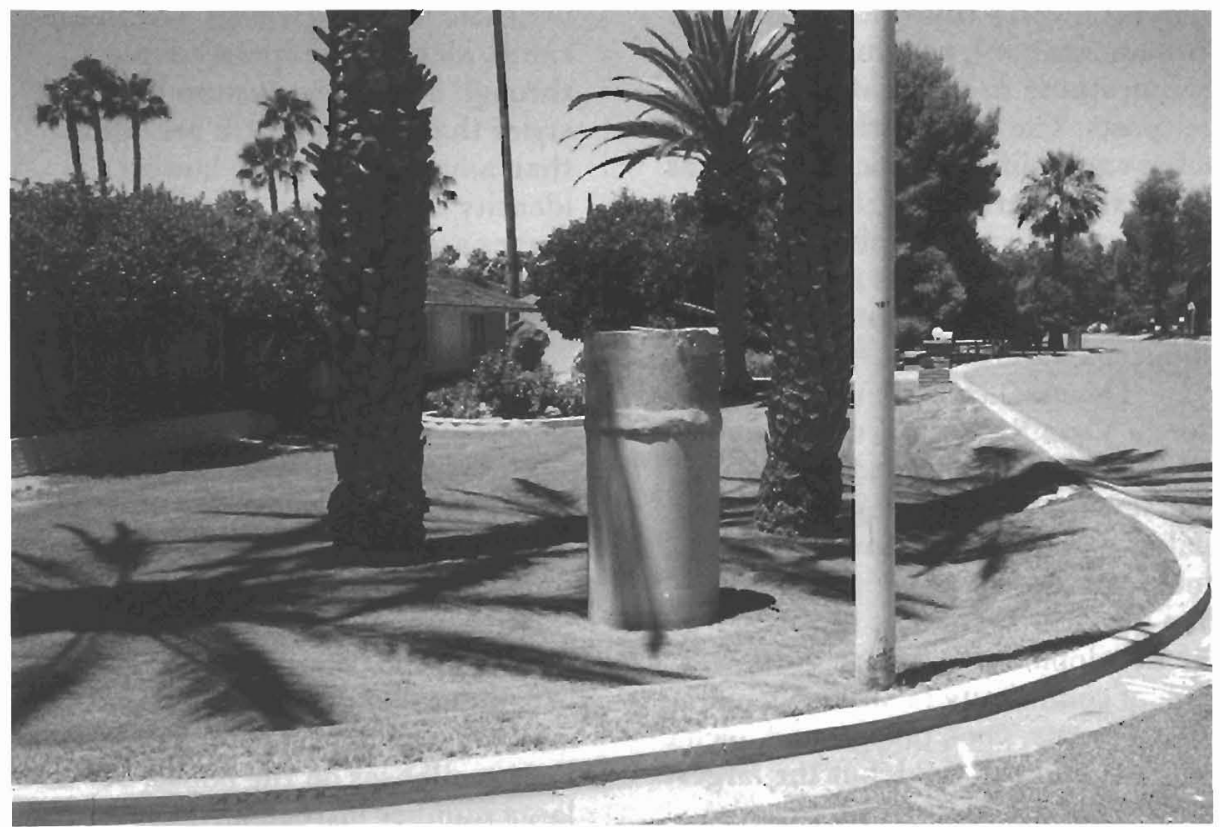

Figure 7. Irrigation equipment, lush vegetation, and lawn edge berms are distinctive "Sunken Citrus" landscape signatures in Arcadia.

Basketball." Play equipment was often observed, whether it was a swing for the little kids or an RV for the "big kids." Basketball goals were more common in this subdivision than any other surveyed (Figure 9), as were boats and boat trailers parked alongside the house or in the carport. planned retirement community in Mesa, marks its turf with perimeter walls and its name on signs at every entrance. Its epitome space emphasizes recreation with clubhouse game rooms and a golf course, and also projects the development name with large letters across a bandstand. As is the case with other middle subdivisions, neighborhood watch signs are common. Every house looks about the same in this tightly controlled environment, but the residents still manage to project a "Name Plates and Home States" identity (Figure 10). Resident names are often displayed on the mailbox or on the house, and home states are advertised in the display of an old license plate on the mailbox or in the yard. All of the yards are xeriscaped, so multi-colored rock art, a personal landscape signature, is practiced with relish. The contention that idiosyncratic ornaments are today rarely seen in the urban landscape (Relph 1987) appears mistaken upon looking at the yards in the middle subdivisions that we visited.

Rialto Hills and Echo Canyon both contain the spray-on stucco houses with red concrete tile roofs that dominate today's new subdivisions, but each still carves out a distinct identity. In both subdivisions the beige house colors vary only slightly, walls surround each backyard and the perimeter of the development, and cul-de-sacs add variety to the street plan. Xeriscaping is common in each development and is even institutionally encouraged in Rialto Hills through a Chandler rebate program for low water-use plantings. Rialto Hills projects a "Spray-on Spanish" identity through its Neo-Mediterranean house and roof style and the abundant Southwestern and Mexican clay pots and statuary in the yards (howling coyotes are a favorite). The name Rialto Hills is nonsensical since rialto is Italian for height and there are no hills nearby, but the name still carries an identity, reinforced by the prominent entryway monument (Figure 3). Most residents think "rialto" is Spanish, so the name fits the "Spray-on Spanish" motif, and the inclusion of hills in the name may be another indication of people creating a con- 
nection with natural features from which they feel isolated.

The individual subdivisions like Echo Canyon within the master planned community of Mountain Park Ranch do not have signs identifying the subdivision by name. The tightly-controlled development of Mountain Park Ranch effectively subsumes the name identity of subdivisions in its effort to create a single and powerful marketing entity. This master planned community aggressively marks its turf at the southern base of Phoenix's South Mountain through massive entryway signs and walls, signs regulating the usage of common paths and parks, and signs telling people what to do with dog waste. The neighborhood features many epitome spaces of green grass, landscaped exercise paths, and elements that are nationally recognized as best sellers: pools, ponds, and pocket parks (Fletcher 1992) (Figure 11). Within Echo Canyon everything is edged with brick - trees, yards, driveways, grassy islands in rock yards, planters--perhaps a signal of both ostentation and a desire to insert a traditional element into a new landscape. In Rialto Hills the yard design and art is more eclectic, even kitschy, whereas in Echo Canyon every yard aspires to match a picture-perfect ideal. The institutional molding of

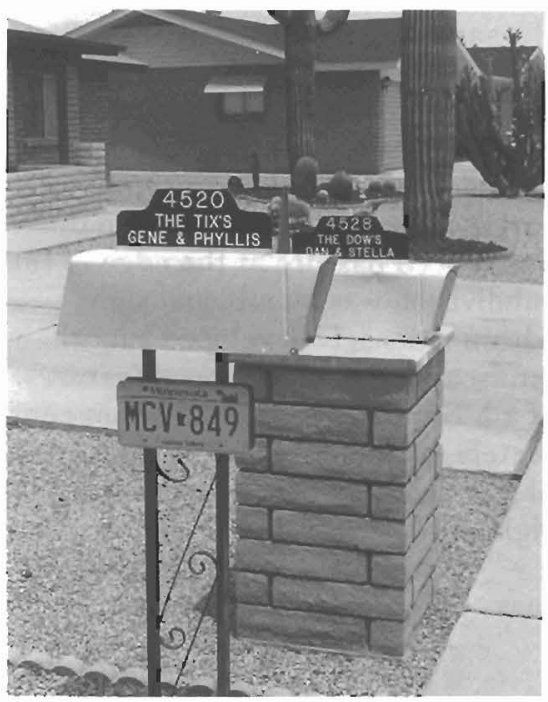

Figure 10. The "Name Plates and Home States" identity of Sunland Village is proudly displayed.
Echo Canyon's housescapes and epitome spaces into a sanitized landscape with signs suggesting appropriate behavior merits the identity tag, "Packaged Ponds and Lawns." Lower-Income Subdivisions. Chain link fences with a gate across the driveway are common front yard enclosures in Sheraton Park, and they also surround the schools. Window bars on simple ranch homes are practically ubiquitous, two houses are boarded shut, and some of the individual

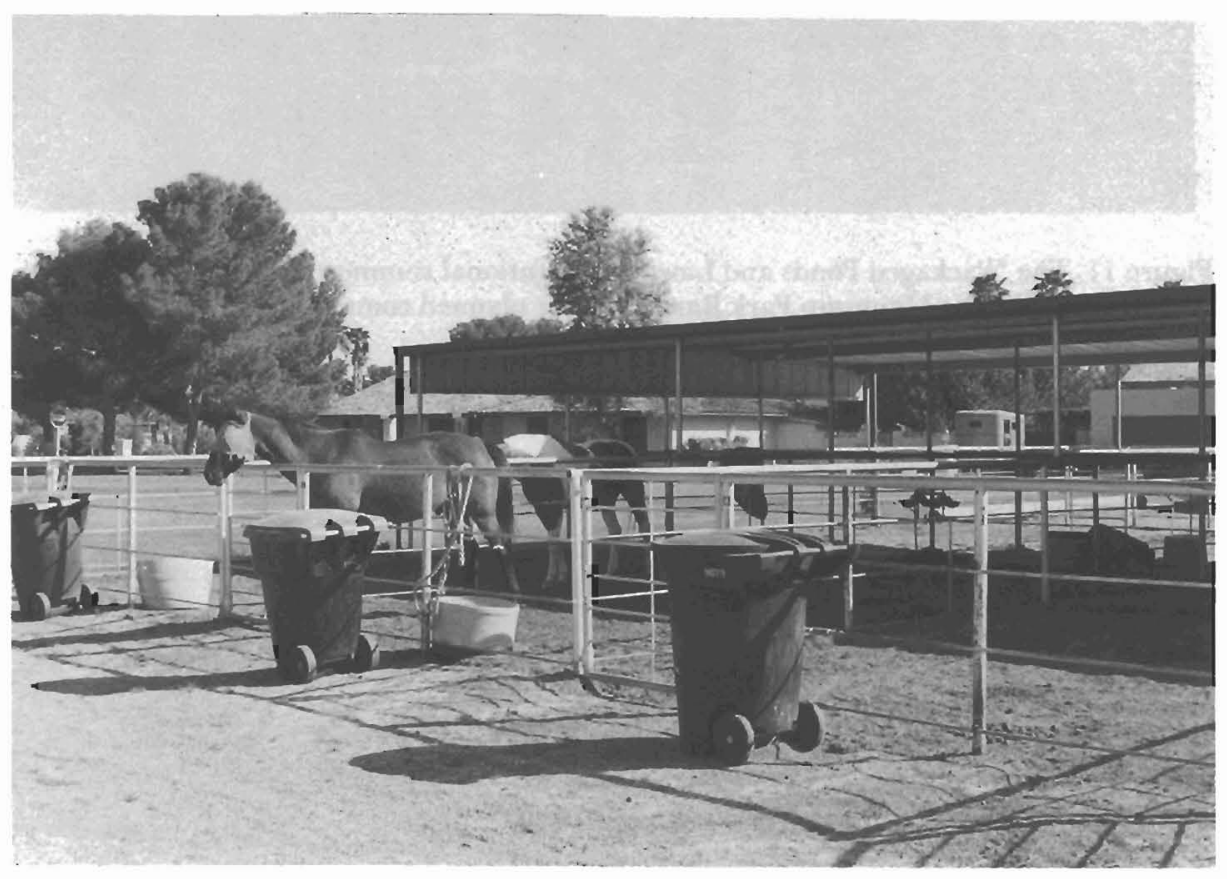

Figure 8. The horse facilities of the epitome space in Buena Vista Ranchos exemplify what makes this subdivision "Horse Heaven."

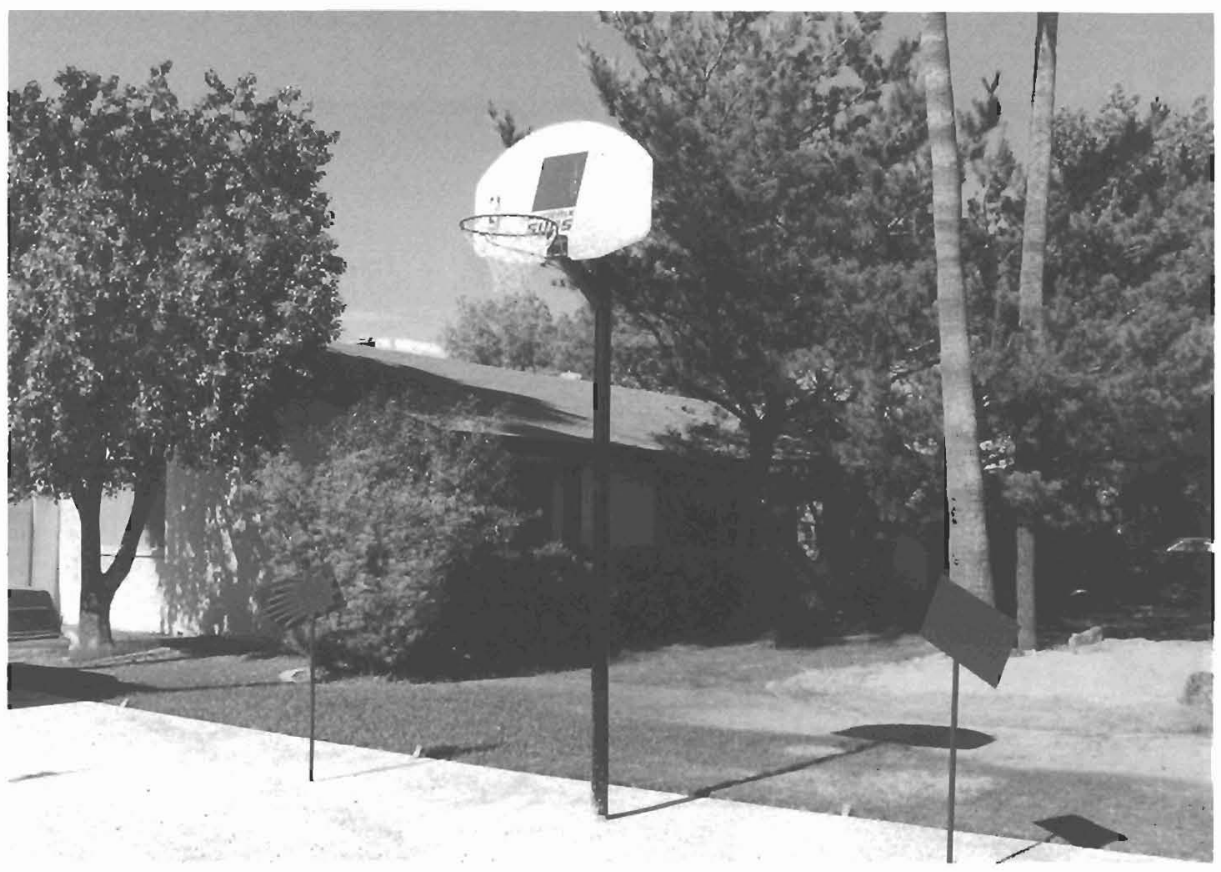

Figure 9. A stylistic basketball play area captures the spirit of the "Boats and Basketball" identity in Tempe Royal Palms. 


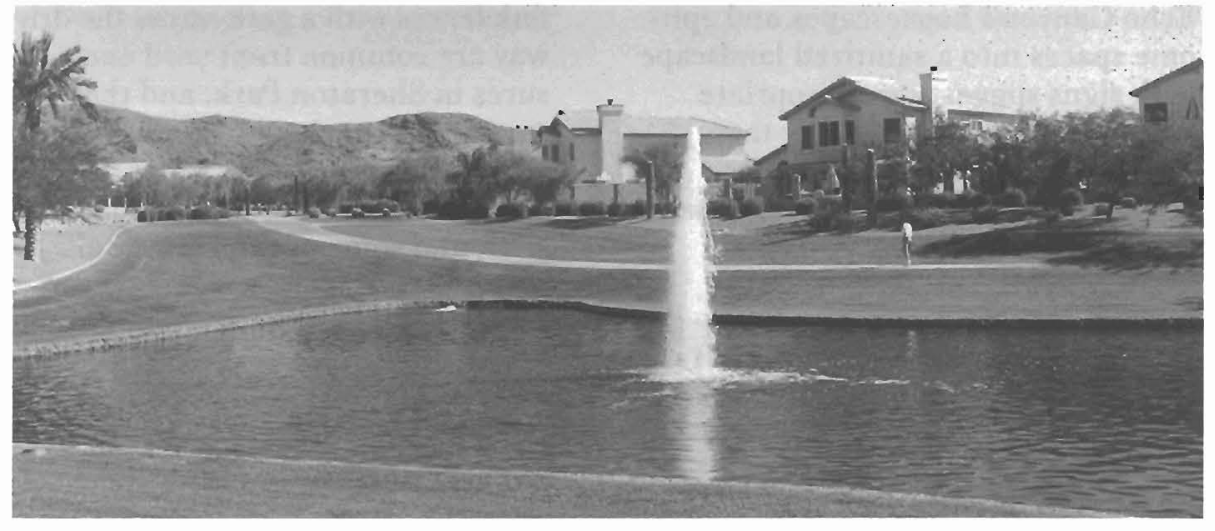

Figure 11. The "Packaged Ponds and Lawns" institutional common space of Echo Canyon is maintained by the Mountain Park Ranch master planned community.

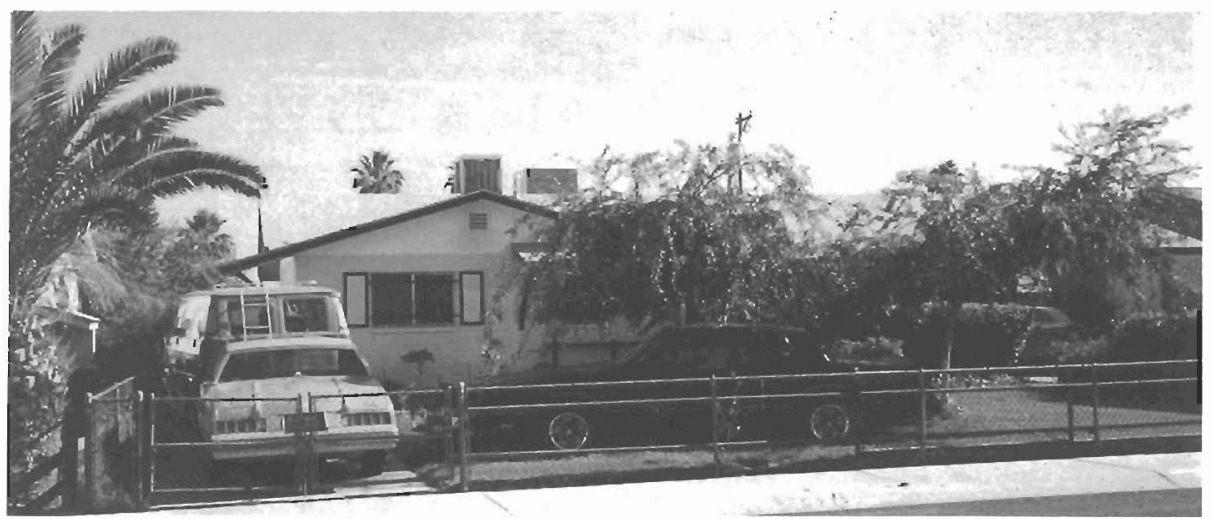

Figure 12. Window bars, vivid house colors (pink in this case), yard parking, and front yard enclosures are personal landscape signatures contributing to Sheraton Park's "Barred Panes and Bright Paint" identity.

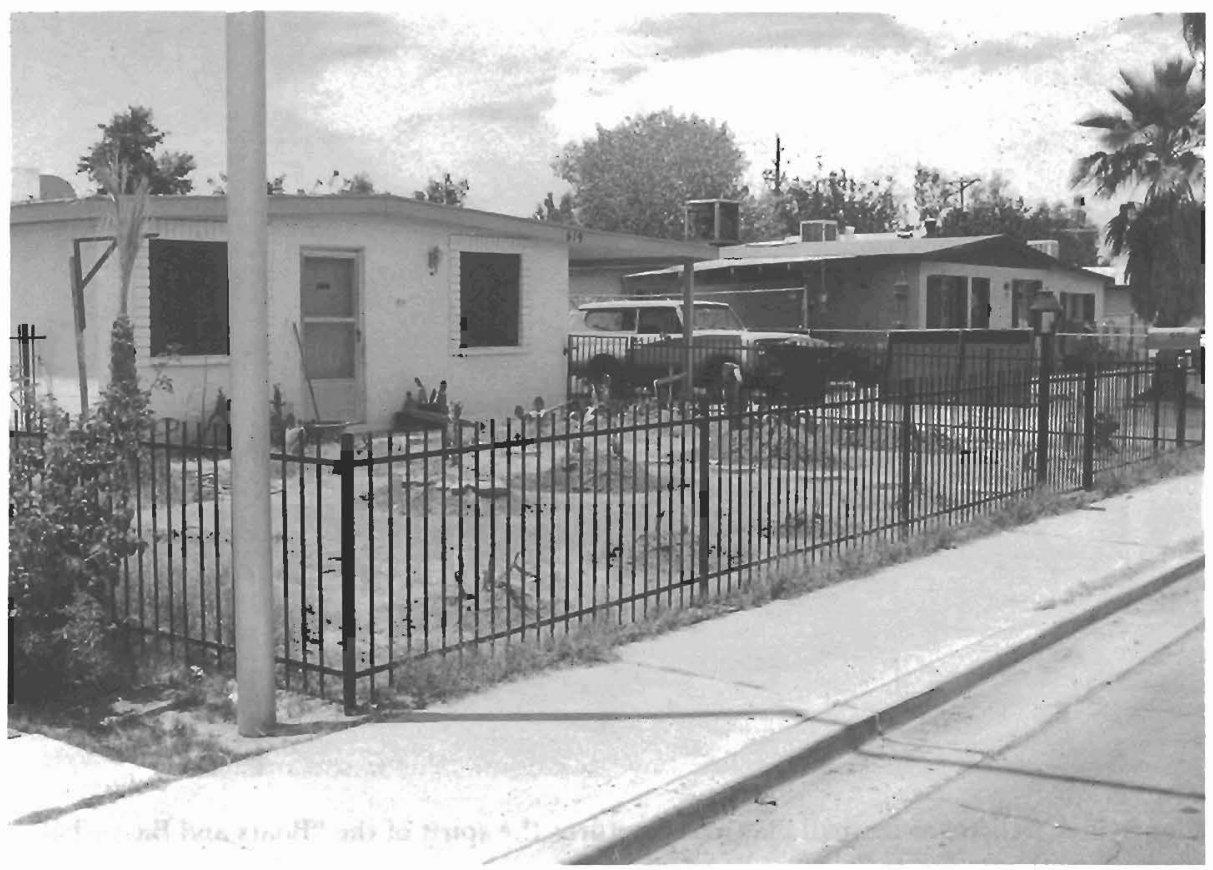

street mailboxes are locked. Even so, this neighborhood had a higher degree of outdoor activity than any other we studied. Although graffiti is thought to be more typical of lowerincome areas, we found it to be rare in Sheraton Park, as in all subdivisions examined. The location of graffiti in metropolitan Phoenix is more often outside the limits of subdivisions on boundary space, places of adjoining land uses. Many of Sheraton Park's bermuda grass lawns are neatly maintained, but great variability exists from yard to yard. Parking operable cars in the yard is common, even when street parking is available (Figure 12). The yard is apparently perceived as a secure place to park a car overnight. Another distinctive landscape element is the common bright house paint, a signal that for the projection of identity, the racial composition of the neighborhood may be more important than its income level. The landscape signatures in Sheraton Park that project identity, including the "Barred Panes and Bright Paint," arc personal, a commonality of lower-priced subdivisions.

Holmes Addition is next to a Mormon ward chapel in central Mesa, and it probably has the fewest signatures of any subdivision. Much of the area is nondescript with only modest amounts of yard art and play equipment. What stands out in the subdivision is the broad palette of house colors, though usually not with the same brightness as in Sheraton Park. This signature, in combination with a few eclectic housescapes (Figure 13), results in a "Patchwork Quilt" identity that is centered on variety. The roadside irrigation ditch and fenced pasture at the edge of this subdivision was an unusual sight within a densely developed suburban landscape, yet these typical features of a Mormon settlement are not completely unexpected finds within a few blocks of a Mormon temple (Francaviglia 1978).

Surrounded for the last twenty years by open fields in all directions

Figure 13. An eclectic housescape, complete with burial mounds in the front yard, contributes to the "Patchwork Quilt" character of Holmes Addition. 
that are only now beginning to fill in, Arcadia Village in Chandler features an amazing variety of house ornamentation hanging from the front eaves and a wide assortment of yard art. The higher than average percentage of Hispanics is represented through some Hispanic surname name plates, a Virgin of Guadalupe shrine, and a car with a large "Sinaloa" (Mexico) sticker. House colors are more muted here than in the other lower subdivisions, but a few feature bright trim paint. The peaceful, country feel of the subdivision is represented by the identity tag "Mulberry Lane," a nickname based on the numerous white mulberry trees (Figure 14). This tree is quickly becoming an unusual landscape signature because, as is the case with the olive, the white mulberry is today rarely planted duc to its production of allergy-causing pollen.

\section{Conclusion}

Table 3 summarizes the frequency of landscape signatures found in the three classes of subdivisions. The number of landscape signatures declines with income, but the lowercost areas still have an identity; they just have fewer institutional signatures to project it. Epitome spaces and turf markers seem to be the best examples of institutional signatures that carry the identity of subdivisions, but only in areas with higher house values. These are the same subdivisions that have active homeowners associations to enforce the deed restrictions that maintain the desired landscape identity.

Location is clearly important to the identity of individual subdivisions. For example, the location within an irrigation district enhances the ability of all three upper-middle-income subdivisions to project a lush, cool, arcadian identity. The open land surrounding Arcadia Village allows country breezes that explain the popularity of wind chimes and whirligigs. Sheraton Park's and Encanto's proximity to high crime districts probably accounts for the preponderance of anti-crime devices in those subdivisions. City political boundaries, however, seem to have little influence on the differences between subdivision identities, with the exception of the Phoenix
Planning Department's efforts to project and protect the neighborhood character of Encanto.

The age of a subdivision is at times a more reliable predictor of its character than are location or house values, particularly with regard to ornamental planting and the degree of homogeneity in house style and color. Yard art and front property line markers seem to be efforts in newer subdivisions to create identity in a xeriscape that even time will have trouble softening. In new subdivisions

\section{TABLE 3.}

Frequency of Selected Subdivision Landscape Signatures. ${ }^{4}$

\begin{tabular}{|c|c|c|c|}
\hline Institutional & & & \\
\hline cul-de-sacs & $\mathrm{C}$ & $\mathrm{C}$ & $\mathrm{R}$ \\
\hline epitome spaces & $\mathrm{O}$ & $\mathrm{Ci}$ & $\mathrm{R}$ \\
\hline house style variety & $\mathrm{O}$ & $\mathrm{R}$ & $\mathrm{R}$ \\
\hline large lots and homes & $\mathrm{C}$ & $\mathrm{O}$ & $\mathrm{R}$ \\
\hline turf markers & $\mathrm{C}$ & C & $\mathrm{R}$ \\
\hline Personal & & & \\
\hline anti-crime features & C & $\mathrm{O}$ & C \\
\hline front yard enclosures & $\mathrm{C}$ & $\mathrm{C}$ & G \\
\hline house ornamentation & $\mathrm{O}$ & $\mathrm{O}$ & $\mathrm{O}$ \\
\hline house color variety & $\mathrm{O}$ & $\mathrm{O}$ & C \\
\hline individualistic mailboxes & $\mathrm{C}$ & $\mathrm{O}$ & $\mathrm{R}$ \\
\hline xeriscaping & C & $\mathrm{O}$ & $\mathrm{R}$ \\
\hline yard art & $\mathrm{O}$ & $\mathrm{O}$ & $\mathrm{O}$ \\
\hline
\end{tabular}

Source: Field observations.

Key: $\mathrm{C}=$ common $\mathrm{O}=$ occasional $\mathrm{R}=$ rare

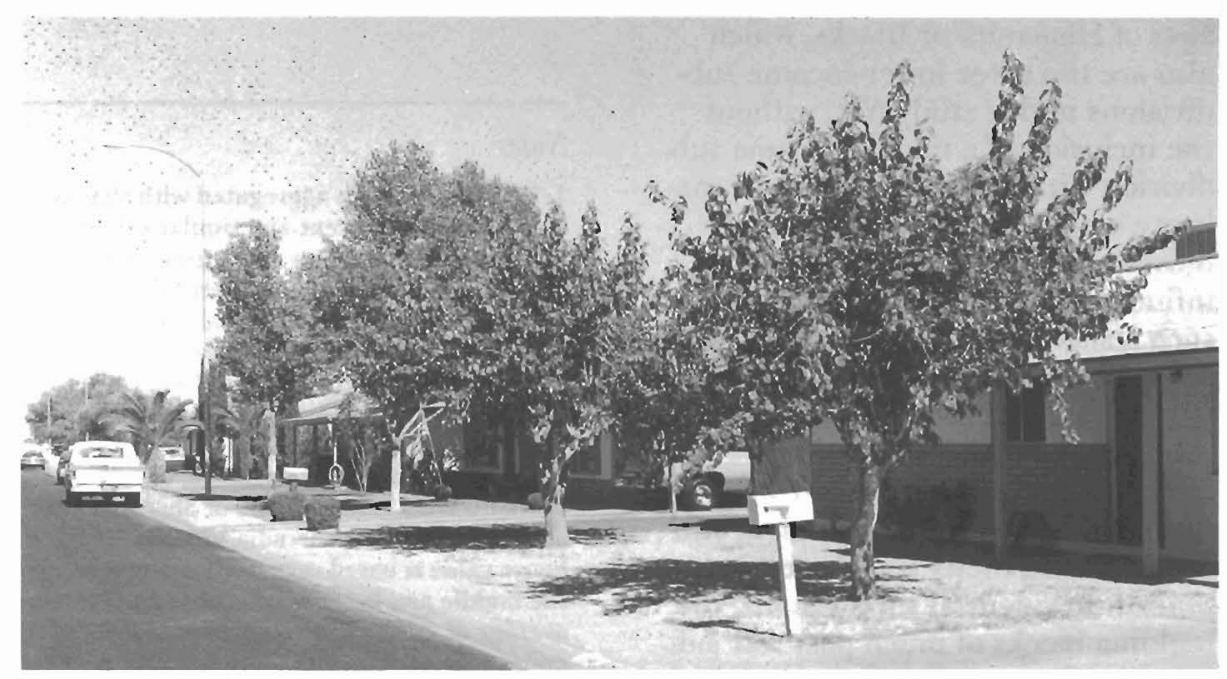

igure 14. Straight streets lined with white mulberry trees and a bucolic setting project a "Mulberry Lane" identity in Arcadia Village.

personal identity is not expressed through the house style, so the yard is yard ornaments are visible clues to gren (1984). Some types of yard art ornate mailboxes, driveway posts, poles, and diminutive figurines. The Arizona equivalents to the numerous and Helgren in the Florida Keys are ered remains of cholla cacti.

(n)


The identity of older subdivisions is likely to be based upon lush ornamental plantings, house style and color, or fence and hedge front yard enclosures. Newer subdivisions are more uniform in their institutional signatures and have more perimeter walls and entry signs than older ones. The enclave-like character of a walled subdivision gives it the appearance of being strongly delimited and differentiated from surrounding developments, a strategy that increases its market profile. Wall and sign turf markers project an identity of seclusion to both residents and outsiders, and they are both a symbolic and material effort to control social interactions. Entryway signs must be maintained, however, or face the fate of one in Arcadia that no longer features a name and now represents identity lost.

Vernacular ornamentation, individualism, and a desire for the freedom to innovate are all expressed through subdivision personal landscape signatures. Personal signatures, such as yard art and front yard borders and enclosures, are most often the source of subdivision identity in metropolitan Phoenix. This could emanate from the relatively uniform appearance of many subdivisions, but it points toward an impressive projection of identity, even in the face of standardized planning procedures and deed restrictions in master planned communities. Personal signatures are key to the projected identity of subdivisions with relatively high percentages of Hispanics or Blacks, which also are the three lower-income subdivisions in this study. Yet, without the inclusion of a middle-income subdivision with a Black or Hispanic majority, we cannot assess how higher incomes and deed restrictions might influence the landscape signatures of such a subdivision.

The frequently heard assertion that suburbia is homogeneous and that somehow its landscapes lack identity is not supported by this research. In fact, the question of suburban homogeneity is in need of reappraisal. Residential subdivisions, the building blocks of much post-war suburbanization, are rich repositories of landscape identity. Perhaps we have not fully appreciated this diversity because so many of our studies have assessed suburbs rather than suburban landscapes. Macro analyses from above certainly contribute to an understanding of urban social patterns, but that view is given greater authority when combined with a meso perspective that incorporates field investigation on the ground. Residential subdivision landscapes in Phoenix exhibit distinct patterns and display preferences of community and group identity.

The paradox of how subdivisions are criticized for having a lack of identity while at the same time serving as an idealizcd American landscape is clarified by a full consideration of the wide range of landscape signatures that result in every subdivision projecting an identity. Institutionally, the ethnic and newer subdivisions lack identity, especially when observed from afar, but personal signatures represent the chance for the residents of each subdivision to create a landscape to match their own vision of what is a model American community.

\section{Acknowledgments}

The authors would like to thank Dave Richter for providing housing sale prices and subdivision plat maps. We also appreciate the comments of Frederick R. Steiner on a draft of this article.

\section{Notes}

1. Encanto data are aggregated with that of Palmcroft, an adjacent and similar subdivision. Sun Valley Estates data are aggregated with that of Jokake Villa and Hidden Village 10, also adjacent and virtually identical subdivisions. Sun Valley Estates, Jokake Villa, and Hidden Village 10 are all in a district of Phoenix that is popularly known as Arcadia. Observations were made in units 2, 3, and 4 of Tempe Royal Palms, unit 8 of Sunland Village, units 1 and 2 of Rialto Hills, units 1 and 2 of Sheraton Park, and units 1 and 2 of Arcadia Village. Mean house value is based upon recent sale prices for the middle and lower subdivisions and upon an average of sale prices and market prices for the upper subdivisions. Ethnicity and race percentages are based on 1990 census block group dat a for pre-1990 developments. Block group area does not correspond precisely with subdivision boundaries, so these percentages are approximations. For subdivisions built since 1990, field observations are the source for the estimated ethnicity and race percentages. Percentages do not always add to 100 because of small numbers of American Indians, Asians, or Pacific Islanders.

2. The 1990 metropolitan Phoenix ethnic and race percentages were $77 \%$ non-Hispanic white (a grouping that is frequently labelled Anglo in the American Southwest), 16\% Hispanic, 3\% Black, 3\% other (U.S. Bureau 1992). Although the imprint of the American Indian population upon the metropolitan Phoenix landscape is highly visible, especially on the large reservations that adjoin several local municipalities, blacks actually constitute the second-largest minority by nearly a two to one ratio over American Indians.

3. More variability exists in the mean house values and landscape characteristics of the middle-income subdivisions than for the upper or lower groups. Three of the middle subdivisions (Encanto, Sun Valley Estates, and Buena Vista Ranchos) could be considered as an upper-middle cat egory.

4. Examples of turf markers are neighborhood watch signs, entryway monuments, perimeter walls, and signs restricting access. Anti-crime features include security systems, motiondetector lighting, window bars, and "beware of dog" signs. Front yard enclosures include hedges, fences, and low, decorative masonry borders. House ornamentation is a decorative feature attached to the house, such as ceramic tile address numbers, name plates, flags and banners, or oversized butterflics.

\section{References}

Arrcola, Daniel D. 1988. "Mexican American Housescapes." Geographical Review 78:299-315. , and James R. Curtis. 1993. The Mexican Border Cities: Landscape Anatomy and Place Personalily. Tucson: University of Arizona Press.

Banerjee, Tridib, and William C. Baer. 1984. Beyond the Neighborhood Unit: Residential Environments and Public Policy. New York: Plenum.

Bookout, Lloyd W., Jr., et al. 1990. Residential Development Handbook. Washington, D.C.: ULI-Urban Land Institute.

Brennan, Dean P. 1994. Planner II, Phoenix Planning Department. Personal Communication, June 3.

Clay, Grady. 1973. Close-Up: How to Read the American Cily. New York: Praeger.

Curtis, James R. and David M. Helgren. 1984. "Yard Ornaments in the American Landscape: A Survey along the Florida Keys." Journal of Regional Cultures 4(1):78-92.

Duncan, James S., Jr. 1973. "Landscape Taste as a Symbol of Group Identity: A Westchester County Village." Geographical Review 63:334-355. 
Findlay, John M. 1992. Magic Lands: Western Cilyscapes and American Culture After 1940. Berkeley: University of California Press.

Fletcher, June. 1992. "Best Sellers." Builder September:85-88.

Francaviglia, Richard V. 1978. The Mormon Landscape: Existence, Creation, and Perception of a Unique Image in the American West. New York: AMS Press.

Gans, Herbert J. 1967. The Leviltowners: Ways of Life and Politics in a New Suburban Community. New York: Pantheon.

Garreau, Joel. 1991. Edge City: Life on the New Frontier. New York: Doubleday.

Girling, Cynthia L, and Kenneth I. Helphand, 1994. Yard Street Park: The Design of Suburban Open Space. New York: John Wiley \& Sons.

Godfrey, Brian J. 1988. Neighborhoods in Transition: The Making of San Francisco's Ethnic and Nonconformist Communities. Berkeley: University of California Press.

"Greater Phoenix Housing Study: Residential Subdivisions." Housing Activily Books, 1973 to 1994. Phoenix: Landiscor Aerial Photo, Inc. of Arizona.

Hecht, Melvin E. 1975. "The Decline of the Grass Lawn Tradition in Tucson." Landscape 19(3):3-10.

Hemphill, Russ, and Michael Murphy. 1994. "Subdividing the Desert." Phoenix Gazette April 17:Gl.

Hough, Michael. 1990. Out of Place: Restoring Identity to the Regional Landscape. New Haven: Yale University Press.

Hugill, Peter J. 1986. "English Landscape Tastes in the United States." Geographical Review 76:408-423.

Jackson, John Brinckerhoff, 1994. A Sense of Place, a Sense of Time. New Haven: Yale University Press.

Jackson, Kenneth T. 1985. Crabgrass Frontier: The Suburbanization of the United States. New York: Oxford University Press.

Kroloff, Reed, 1993. "Valley of the Tiles Drowning in Fake-Mexican Houses." Arizona Republic December 16:E1.

Lansing, John B., and Robert W. Marans. 1969. "Evaluation of Neighborhood Quality."
Journal of the American Institute of Planners 35:195-199.

Leroux, Charles. 1993، "U.S. Middle Class Defies Definition." Arizona Republic March 14:A1.

Lewis, Peirce F. 1979. “Axioms for Reading the Landscape: Some Guides to the American Scene." In The Interpretation of Ordinary Landscapes: Geographical Essays, edited by D. W. Meinig, pp. 11-32. New York: Oxford University Press.

Luckingham, Bradford. 1989. Phoenix: The History of a Southwestern Metropolis. Tucson: University of Arizona Press.

Lynch, Kevin. 1960. The Image of the City. Cambridge: M.I.T, Press.

Martin, John. 1994. President, Jomar Management. Personal Communication, June 1.

Meinig, D. W., ed. 1979. "Symbolic Landscapes: Models of American Community." In The Interpretation of Ordinary Landscapes: Geographical Essays, pp. 164-192. New York: Oxford University Press.

Palm, Risa. 1982, "Reconsidering Ciontemporary Neighborhoods." Landscape $26(2): 17-20$.

Pascoe, Neal. 1995. Town Planner, Town of Paradise Valley. Personal Communication, January 10.

Peterson, Gary G., and Thomas F. Saarinen. 1986. "Local Symbols and Sense of Place." Journal of Geography 85:164-168.

Relph, Edward. 1987. The Modern Urban Landscape. London: Croom Helm.

Richter, Dave. 1994. Executive Sales Associate, Coldwell Banker Success Realty. Personal Communication, June 2,3,4.

Rowe, Peter G. 1991. Making a Middle Landscape. Cambridge: MIT Press.

Salter, Christopher L. 1978. "Signatures and Settings: One Approach to Landscape in Literature." In Dimensions of Human Geography: Essays on Some Familiar and Neglected Themes, edited by Karl W. Butzer, pp. 69-83. Chicago: University of Chicago Department of Geography, Research Paper 186.

Sargent, Charles, ed. 1988. Metro Arizona. Scottsdale: Biffington Books.

Schwartz, Janet. 1980. "The Poet and the Pastoral in the Naming of Suburbia." Names 28:231-254.

Shat tuck, Liz. 1994. Marketing Analyst, Continental Homes. Personal Communication, June 6.

Stern, Robert A. M. 1986. Pride of Place: Building the American Dream. Boston: Houghton Mifflin.

Stilgoe, John R. 1988. Borderland: Origin of the American Suburb, 1820-1939. New Haven: Yale University Press.

Tuan, Yi-Fu. 1974. Topophilia: A Study of Environmental Perception, Attiludes, and Values. Englewood Cliffs: Prentice-Hall, Reprint, New York: Columbia University Press, 1990.

U.S. Bureau of the Census. 1992. Census of Population and Housing. Summary Tape File 1A, 1990, CD-ROM. Washington, D.C.: U.S. Government Printing Office.

U.S. Bureau of the Census. 1993. Census of Population and Housing. "Table 8: Race and Hispanic Origin, 1990." In Population and Housing Characteristics for Census Tracts and Block Numbering Areas, Phoenix, $A Z$ $M S A$, Section 1, issued May. Washington, D.C.: U.S. Government Printing Office.

Weightman, Barbara A. 1981. "Arcadia in Suburbia: Orange County, California." Journal of Cullural Geography 2(1):55-69.

Winters, Christopher. 1979. "The Social Identity of Evolving Neighborhoods." Landscape 23(1):8-14.

Worley, William S. 1990.J. C. Nichols and the Shaping of Kansas City: Innovation in Planned Residential Communities. Columbia: University of Missouri Press.

Zelinsky, Wilbur. 1988. "Where Every Town is Above Average: Welcoming Signs on America's Highways." Landscape $30(1): 1-10$. 